\title{
ODNOS PRAVA I MOĆI U PRAVNOM PORETKU*
}

\author{
Marko Trajković \\ Univerzitet u Nišu, Pravni fakultet
}

dnos prava i moći u pravnom poretku jedne zemlje direktan je uzrok njene stabilnosti. Od ovog odnosa direktno zavisi kako će izgledati slika tog pravnog poretka, kao i koliko će takav pravni poredak biti dugotrajan. Moć koju samo po sebi nosi pravo, jer jezik prava nije „nevin“ već sama po sebi utiče na stabilnost, a ako tome dodamo odnos faktičke moći stvar postaje veoma ozbiljna i o njoj se mora razmišljati. Dakle, pravilno „razmeštena“ i vrednosno „uređena“ moć doprineće stabilnosti jednog poretka koji se želi nazvati pravnim.

Ključne reči: pravo, moć, pravni poredak, vrednosti, dugotrajnost

\section{Uvod}

7avodljivost moći se najbolje može videti na primeru vlasti koja se zasniva na organizovanoj sili kojom raspolaže država. Ovo zato jer „Die macht findet ihre Grenze nicht an der Gewalt. Macht ist Geist: alleMacht ist letzen Endes macht über die seelen“.' Ta državna vlast je najslabija tačka na kojoj se svi stubovi prava mogu srušiti, a pravni sistem može da izgubi svoj autoritet, ako autoritet shvatamo kao vrednost, a ne kao puku fizičku moć države. Pošto se čisto formalno-pravno posmatrano, državna vlast sastoji u stvaranju i primeni prava, pitanje zavodljivosti moći postaje posebno interesantno za ceo pravnički stalež. Posebnu notu ovoj zavodljivosti daje i činjenica da je državna vlast samo izraz društvene vlasti među ljudima, koja se zasniva na odnosima nadređenosti i podređenosti, te se samim tim sastoji u nametanju volje.

Kako samo državna vlast može jedina da u društvu primenjuje organizovanu silu to nju odmah kvalifikuje za najsnažniji element jednog društva, koji može da čini skoro sve što poželi ali ne i da „sahrani“ pravo, ius orbitur vi. Pošto počiva na autoritetu, auctoritas i sili, vis ona može da ulije poštovanje, a sila strah. Oni se međusobno dopunjuju, jer je autoritet bez sile nemoćan, a sila bez autoriteta slepa.

Zato vlast koja se javlja kao bitan „politički slogan“2 koji može da zavodi bolje od bilo čega. Sada se može postaviti pitanje ravnoteže između moći, vlasti i vrednosti, te je sa-

\footnotetext{
* Ovaj članak je rezultat istraživačkog rada u okviru projekta br. 179046 „Zaštita ljudskih i manjinskih prava u evropskom pravnom prostoru“ Pravnog fakulteta u Nišu koji finansira Ministarstvo za nauku i tehnološki razvoj Republike Srbije.

* Dr Marko Trajkovć je redovni profesor.

${ }^{1}$ G. Radbruch, Rechtsphilosophie, Verlag Von Quelle \& Mezer in Leipzig, Leipzig 1932. 79.

${ }^{2}$ A. Marmor, Law in the Age of Pluralism, Oxford University Press, New York, 2007, 3.
} 
svim moguće izvesti zaključak da je vladavina prava najviše cenjena tamo gde je ranije bila ignorisana. ${ }^{3}$ Te se zato kao večita i često neispunjena želja onih podjarmljenih pojavljuje ponovo i ponovo ideja da njima vlada pravo, jer je vladavina prava bila uvek vezivana za valjano uređeno društvo. ${ }^{4}$

U situaciji kada želimo da izbegnemo zavodljivost moći mi se okrećemo prema pravu koje poštuje slobodu i ljudsko dostojanstvo. ${ }^{5}$ Zašto? Razlog je jednostavan, zavodljivost moći je nešto što se teško može izbeći, jer svaka vlast kvari, a ljudi zaslužuju da vlada pravo, a ne puki voluntarizam vlasti. Problem nastaje kada iz teških istorijskih faza koje odlikuje svirepost rata i čoveka, ljudi požele nešto nerealno, a to je da njima vladaju savršeni zakoni. Zašto je ova renesansa učenja o vladavini zakona bez ljudi nerealna? Kod ovog pitanja započinju ciklični krugovi neraspoloženja. Ti se ciklični krugovi javljaju u trenutku kada bežeći od surovosti rata ljudi krenu u istraživanje mogućnosti da njima vladaju savršeni zakoni, a onda pošto uvide da tako nešto ne postoji, oni gube veru i bivaju izloženi društvenoj nesigurnosti koja počinje da se širi čim u društvu nema čvrstih pravila. Tada a iz straha, ljudi ulaze baš u ono stanje iz kojeg su tako jako želeli da izađu, ulaze u diktaturu. Ljudska istorija pokazala je primere takvih koncentričnih krugova, koji se neumitno ponavljaju. Valjalo bi naći neku ravnotežu koja će doprineti razvoju društva, a ne njegovom paralizovanju. Zato ideji „vladavini prava, a ne ljudi“6 valja prići sa realnih polazišta, a to je najpre izgradnja vrednosnog mentaliteta nasuprot zavodljivosti moći kod onih koji vladaju, dakle onih koji će svojim pravnim propisima usmeravati ljudsko ponašanje. Iz ovog razloga i sama pravna pravila moraju biti takva da ih je moguće primeniti. ${ }^{7}$ Naravno da ovo odmah iziskuje stvaranje vrednosnog mentaliteta kod onih koji vladaju, te na taj način gradimo još jedan stub prava, valjanu vladu jer: „As Raz rightly noted, we must be governed by human beings, not just by law. Is human beings, namely, legislators, judges, and countless other officials, who make the law and apply it, and this is, presumably, as it should be" ipak "This slogan cannot really mean what it literally states. Perhaps sometimes it meant to suggest that those people who are assigned the role of making laws should be subject to the laws they enact". 8 Dakle, slažemo sa sa Razom (Joseph Raz), mi ćemo biti uvek pod vladavinom ljudi, jer su ljudi sudije i zakonodavci, ali izgradnjom vrednosnog mentaliteta ti zakonodavci i te sudije biće bolji.

Time se izbegava zavodljivost moći kod zakonodavca i sudije, te je zato jasno da, kako je Raz primetio misleći na delatnost državne vlasti, da postupanje vlasti koje nije saglasno zakonu, u smislu stvari po sebi i nije postupanje odgovorne vlasti, kakva bi svaka vlast morala da bude. ${ }^{9}$ Te sasvim prirodno postaje jasno da se zavodljivost moći izbegava time što će se jasno odrediti da je svako postupanje državne vlasti koje je suprotno zakonu nezakonita delatnost. $^{10}$

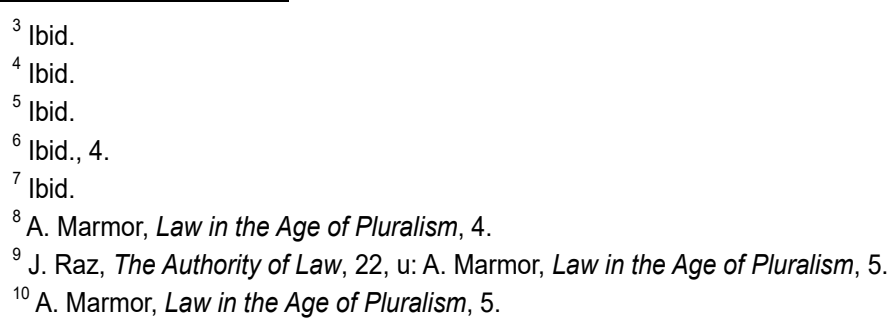


Dakle, ako insistiramo na sili kako onda da država vlada, ako ne putem zakona? Možda koristeći i šireći teror? ${ }^{11}$ A teror je direktna posledica zavodljivosti moći. Tada postaje jasno da nije „kein in sich selbst ruhendes Staatsystem, sondern nur ein geschickt geformtes Instrument der einfachen Diktatur". ${ }^{12}$

\section{Moć i pravo}

Krećemo se u cikličnim krugovima razočarenja građana posebno u zemljama sa nestabilnim pravnim sistemima te se postavlja kao pitanje da li je uopšte moguće govori o vlasti u vrednosnom smislu koja svoje ciljeve postiže mimo zakona? ${ }^{13}$

Istorija je pokazala kako je lako doći od stubova do krhotina prava. Mi možemo da sledimo veoma krutu postavku prava kao naredbe, tada svako pravilo kojem je obezbeđena sankcija suverena postaje po definiciji pravo kojem dugujemo poslušnost. ${ }^{14}$

Međutim, ostaje kao pitanje da li je to dovoljno da bismo rekli da postoje stubovi prava? Pravo je ipak nešto više od zapovesti suverena, te je i sama ideja vladavine prava blisko povezana sa idejom dobro uređenog društva. ${ }^{15}$ Stizanje do društva koje je valjano uređeno je moguće samo uz dobre stubove prava, te tako stubovi prava predstavljaju vrednost koja vodi daljem vrednosnom usavršavanju prava, i vodi i drugim vrednostima koja onda samostalno procenjujemo. Na taj način stubovi prava mogu se shvatiti ne samo kao moralne, društvene i pravne vrednosti, već i kao moralno političke vrednosti, te je tako valjan zaključak da: „There is always something to be said for treating people with formal fairness, that is, in a rational and predictable way, setting public standards for citizens' conduct and officials' response there to... That indeed, is what we mean by the Rule of Law" ${ }^{\prime 16}$ (Neil MacCormick). Suprotno, stanje država u kojima su stubovi prava potisnuti i oštećeni, okreće nas ka krhotinama prava. Ovo se stanje može izbeći izgradnjom vrednosnog mentaliteta zakonodavaca i sudija kako bi se umanjile štetne posledice loših postupaka vlasti i izbeglo zlo. Mnoge moralne vrednosti usmerene su ka izbegavanju zla, a manje ka promociji dobra, te iz tog razloga Raz konstatuje da nije svako izbegavanje zla nešto što valja da bude nagrađeno, te tako osoba koja nije bila u mogućnosti da otruje drugu nikako ne može da zasluži moralnu pohvalu za to. Takva moralna pohvala se može zaslužiti kada postoji iskušenje i mogućnost izbora, kao i nastojanje da se odupremo zlu. ${ }^{17}$

U tom nastojanju da, izbegavajući zavodljivost moći, ne stignemo do krhotina prava, nekada ćemo kao realnost prihvatiti sledeću mogućnost koja će nas ipak navesti na dublje ispitivanje problema, nego što je čisto zgražavanje nad nemogućnosti sistema da funkcioniše sasvim valjano. Tako čak i kada bi postajala situacija u kojoj pojedinci ili određene grupe ljudi nisu u mogućnosti da počine ubistvo, te zbog toga ne možemo reći da

\footnotetext{
${ }^{11}$ Ibid.

${ }^{12}$ L. Bernhard, Der Staatsgedanke des Faschismus, 1931, S. 42, u: G. Radbruch, Rechtsphilosophie, 68.

${ }^{13}$ A. Marmor, Law in the Age of Pluralism, 5.

${ }^{14}$ Ibid., 5-6.

${ }^{15}$ A. Marmor, Law in the Age of Pluralism, 7.

${ }^{16}$ Ibid., 34.

${ }^{17}$ Ibid., 35.
} 
zaslužuju moralnu pohvalu, ipak bismo morali da kažemo da je dobro što je potencijalno zlo izbegnuto. ${ }^{18}$

A kako izgleda ceo problem ako ga postavimo ovako: „I can lie to you unless I communicate with you“. ${ }^{19}$ Dakle, ako nema države nema ni državne vlasti, a ako nema nje onda nema ni zloupotrebe državne vlasti. Onda sledi ako nema prava, onda nema ni razloga da ono bude izbegnuto ${ }^{20}$ niti postoje ona zla koja su stvorena postojanjem prava. Opet sve ovo "negodovanje" dovodi do prethodnog pitanja, da li je uopšte moguće da društvo funkcioniše bez države i prava? Ipak, moramo da zaključimo da je nemoguće da čovek danas postoji bez države i prava. lako je bilo učenja o odumiranju države i prava ona su se pokazala kao netačna, te opet Raz tačno zaključuje da je demokratija opravdana samo ako vodi valjanoj vladavini, ${ }^{21}$ a ne do krhotina prava.

\section{Šta kada pravni sistem počne da nestaje?}

Da li smo u stanju da vidimo „hladne ruke zla“? ${ }^{22}$ To je moguće ako: „Nastoj da budeš kao planina Fudžimori. Sa tako čvrstim i širokim podnožjem da ni najjači potres ne može da te pokrene. Toliko visok da ti i najviša dostignuća beznačajnih ljudi izgledaju ništavno iz tvoje perspektive. Kada ti je um tako visoko kao planina Fudžimori, tek onda možeš da vidiš stvari sasvim jasno. I možeš da vidiš sve sile koje su na delu u oblikovanju događaja $\mathrm{i}$ to ne samo onih koje se događaju u tvojoj neposrednoj blizini“. ${ }^{23}$ Dakle, nama je izgleda često potrebna planina da bi videli šta sledi nakon zavodljivosti moći.

Najpre se uvidom u a hroniku jednog nestajanja dešava gubitak autonomije ličnosti, a pravo na autonomiju je pravo koje proističe iz društvenog i političkog okruženja koje omogućava ljudima da vode svoje živote onako kako oni žela, dakle sasvim prema načelu autonomije ličnosti. ${ }^{24}$ Naravno, ovo dalje zahteva takvu političku strukturu države i društva u kojoj svi imaju jednaku šansu da učestvuju, ${ }^{25}$ a što se mora postići kako bi se izbegle krhotine prava.

Veoma često ceo proces nestajanja započinje čovekovim prikrivanjem sopstvene odgovornosti za „moralno zlo“ koje činimo drugima, zato i „Sv. Avgustin pravi razliku između „moralnog zla“, misleći na zlo koje ljudi čine po svom izboru i znajući da čine pogrešno, i „prirodnog zla," onog koje se odnosi na nepogode koje se jednostavno dešavaju: fatalne

\footnotetext{
${ }^{18}$ „Similarly, the fact that a properly functioning legal system cannot sanction certain form of arbitrary force or violation of human freedom and dignity is simply good, even if it is true that the law does not deserve moral credit for it“.lbid.

${ }^{19}$ A. Marmor, Law in the Age of Pluralism, 35.

${ }^{20} \mathrm{lbid}$

21 J. Raz, Liberalism, Skepticism and Democracy, 778-779, u: A. Marmor, Law in the Age of Pluralism, 59.

${ }^{22}$ L. Najt-Jađik, Reč urednika inostranog izdanja, u: A. M. Lobačevski, Politička poneorologija, Naučna studija o prirodi zla prilagođenog za političke svhe, Beograd, 2011, 9. I u izdanju na engleskom jeziku: L. KnightJadczyk, Editor's Preface, u: A. M. Łobaczewski, Political Ponerology, A science on the nature of evil adjusted for political purposes, Red Pill Press, New York, 1998, 7.

${ }^{23}$ lbid.

${ }^{24}$ A. Marmor, Law in the Age of Pluralism, 62.

${ }^{25}$ A. Marmor, Law in the Age of Pluralism, 62.
} 
bolesti, katastrofe poput vulkana, poplava, uragana i sličnog“. ${ }^{26}$ Tim svojim nastojanjem da prikrijemo svoju odgovornost kao da zapravo gradimo hronologiju nestajanja, te izgleda da je ljudska istorija, kada se objektivno posmatra, jedna „strašna stvar“. ${ }^{27}$ Ovakva istorijska situacija je nažalost veoma često i vodila ka krhotinama prava, kao što je takođe: „Aber von der konkreten Individualität mit allen ihren Launen, Grillen und Spleens führt überhaupt kein Weg zu einer allen gleichermaßen dienenden rechts und Staatsordnung („Allen zu gefallen ist unmöglich“), vielmehr nur zur Verneinung jedes Rechts und jedes Staates“. ${ }^{28}$

Šta pogoduje ovakvoj situaciji nestanka? Jedna posebna vrsta upravljača koje možemo označiti kao psihopate, a njih je moguće odrediti kao „ljude u svakom pogledu, osim u jednom - nedostaje im duša! I to ih čini vrlo efikasnim mašinama. Takve mašine mogu da pišu sholastičke radove, imitiraju reči emocija, ali vremenom postane jasno da njihove reči ne prate njihova dela". 29

Ovakvi ljudi na čelu bilo koje države vode direktno do krhotine prava, sve se to dešava unutar sistema „sile i tlačenja“. ${ }^{30}$ Istorija je dala više takvih primera sistema koji su počivali na teroru umesto na pravu, na „ideološkoj čistoti““11 umesto na vrednostima, što je sve vodilo ka „,histeričnim stanjima“"32 u kojima je „histerična“ ličnost autoritarnog vođe dolazila do izražaja u najgorem mogućem smislu reči. Te tako „Lenjin treba da bude uvršćen u prvu i najkarakterističniju vrstu paranoidne ličnosti, što je najverovatnije izazvano oštećenjem međumozga (diencephalon). Vasilije Grosman opisuje njegove simptome na sledeći način: Lenjin je uvek bio pun takta, blag i ljubazan, ali ga je istovremeno obeležavao oštar nepopustljiv i brutalan stav prema političkim protivnicima. Nikada nije dopuštao ni najmanju mogućnost da bi oni i minimalno mogli biti u pravu, niti da bi on sam i minimalno mogao grešiti. Često je nazivao svoje oponente piljarima, lakejima, slugama, ćiftama, agentima ili podmitljivim Judom, koji se može kupiti za trideset zlatnika. Nije pokušavao da uveri svoje oponente tokom rasprave. Nije razgovarao sa njima, već s onima koji su prisustvovali raspravljanju, da bi se narugao i umanjio ugled svojih suparnika. Nekada je kao takvih svedoka bilo samo nekoliko ljudi, nekada hiljade delegata kongresa, a nekada gomile čitalaca dnevnih novina“. ${ }^{33}$ Ono sto je ostalo iza Lenjina (Влади́мир Ильи́ч Улья́нов Ле́нин) najbolje je oslikano rečenicom: „Geister wie gespenster mag man nach Beliben rufen könen, aber man kann sie nicht nach Beliben wieder heimschicken". ${ }^{34}$

U ovoj hronici valjalo bi takođe videti šta se dešava sa vama kada vas vođa „izbaci iz svog srca“. ${ }^{35}$ Ovo pitanje na vodi ka tome da bi i „Josif Visarionovič Džugašvili, poznat kao Staljin, trebao da bude uključen u listu posebno poneorogenične karateropatije koja se razvi-

\footnotetext{
${ }^{26}$ L. Najt-Jađik, Reč urednika inostranog izdanja, u: A. M. Lobačevski, Politička poneorologija, studija o prirodi zla prilagođenog za političke svhe, 9 .

${ }^{27}$ Ibid., 19.

${ }^{28}$ G. Radbruch, Rechtsphilosophie, 60.

${ }^{2929}$ L. Najt-Jađik, Reč urednika inostranog izdanja, u: A. M. Lobačevski, Politička poneorologija, studija o prirodi zla prilagođenog za političke svhe, 19.

${ }^{30}$ A. M. Lobačevski, Politička poneorologija, studija o prirodi zla prilagođenog za političke svhe, 134.

${ }^{31}$ Ibid., 164.

32 Ibid., 168..

${ }^{33}$ A. M. Lobačevski, Politička poneorologija, studija o prirodi zla prilagođenog za političke svhe, 108.

${ }^{34}$ G. Radbruch, Rechtsphilosophie, 59.

${ }^{35}$ A. M. Lobačevski, Politička poneorologija, studija o prirodi zla prilagođenog za političke svhe, 112.
} 
la na osnovu prenatalnog oštećenja predfrontalne oblasti mozga. Književnost i novine obiluju nagoveštajima takve vrste: brutalan, harizmatičan, ukrotilac otrovnica; donošenje neopozivih odluka; nehumano okrutan; patološki osvetoljubiv prema svakome ko bi mu stao na put; sebično uverenje u sopstvenu genijalnost iako je reč o osobi čiji je um u stvari bio samo prosečan. Takvo stanje objašnjava njegovu psihopatsku zavisnost od osoba, kao što je bio Berija“. ${ }^{36} \mathrm{Na}$ žalost to nisu jedini „primeri“ ovako „nadarenih“ vođa i takođe nisu retki „primeri“" prošlosti, već i realna opasnost koja će se pojaviti i u budućnosti. Ti „staljinistički karakteri“37 nisu samo stvar koja se dešava tamo negde, oni se mogu naći i u našem sokaku.

Mi možemo govoriti o konkretnoj ličnosti, o konkretnom vođi u određenom istorijskom trenutku, ali je takođe moguće da govorimo i o „poneorološkoj zajednici ili grupi“ a za sve njih je karakteristično da imaju „neku svoju posebnu ideologiju koja uvek opravdava njene aktivnosti i opskrbljuje njenu motivacionu propagandu. Čak i omanja banda bitangi može da ima neku svoju melodramatičnu ideologiju i patološki romantizam. Ljudska priroda traži da zle stvari imaju oko sebe naglašen oreol tajnovitosti kako bi se svest - samog čoveka ili nekih drugih - mogla smiriti, a svest i kritičnost prevariti“" ${ }^{38}$ Postojanje ovakvih grupa, samo potvrđuje da je „histerično“ vreme nešto što može da iznedri ovakve grupe kao i da naglasi autoritarne karakteristike ličnosti pojedinaca koji u čudnovatom spletu okolnosti dolaze do vlasti, jer „Praktično je nemoguće da se histerija ispolji kao neka obična individualna pojava, jer je ona zarazna i širi se preko psihičke rezonance, identifikacije i imitacije“. ${ }^{39}$ Ovo „histerično“ vreme obično započinje sa „periodom duhovne krize u društvu, koju istoriografija povezuje sa iscrpljivanjem ideoloških, moralnih i religijskih vrednosti koje su do tada nadahnjivale dato društvo" a ovome pogoduje i narasli egoizam koji dovodi do toga da je vlada date države „blokirana“ te se i država nalazi „bespomoćna da se suoči s problemima koji bi u nekim drugim uslovima bili rešeni bez većih poteškoća“. Ova se faza prema Lobačevskom (Andrew M. Łobaczewsk)i naziva „društvena histerizacija“ nakon čega će uslediti kao sasvim prirodni tok događaja faza koju odlikuju „krvave tragedije, revolucije, ratovi i padovi imperija“. 40

Dalje će u razvoju ovakvih tendencija Lobačevski dodati i stvaranje generacija koje su naučili „kako da potisnu iz polja svoje svesti neugodne misli koje ukazuju na to da njihovi roditelji izvlače korist za sebe na osnovu nepravdi koje čine drugima" te tako dalje oni „izrastaju u donekle histerične osobe koje na već pomenuti način prenose svoju histeriju na sledeću generaciju“. ${ }^{41}$ Ako se ovo nastavi i ako društvo ne može da se odupre ovakvim tendencijama rezultat će sasvim sigurno biti „ogromna i krvava tragedija“. ${ }^{42}$

Ovakvi „opšti zakoni o poreklu zla“43 potpuno su suprotni čovekovoj vekovnoj želji za „srećnim vremenima, ispunjenim spokojem i pravdom"44 koje karakteriše „razumevanje,

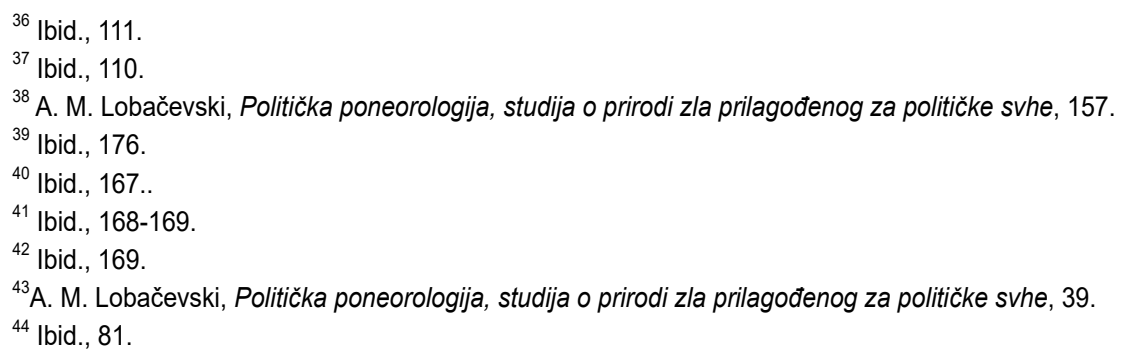


opraštanje, ljubav“. ${ }^{45}$ Ono što ovakva situacija donosi je strah, koji se polako ali sasvim sigurno uvlači u ljude, jer „strah je najveći prijatelj tiranije“. ${ }^{46}$ Iz tog straha kao i zbog sopstvenog komformiteta „Tokom „dobrih" vremena potraga za istinom postaje neugodna jer otkriva neprijatne činjenice. Bolje je misliti o lakšim i prijatnijim stvarima“. ${ }^{47}$ A ovo predstavlja veoma veliku grešku, jer stvari koje su samo gurnute pod „tepih“ pomaljaju svoju „ružnu“ glavu kada je društvo najslabije.

Ovakvo vreme istovremeno oduzima ljudima moć „zaključivanja i sposobnost da se upotrebi zdrav razum“48 koji je potreban kada naiđu nestabilni periodi kada bi ljudi moraju „da prikupe sve svoje fizičke i duhovne snage kako bi se borili za opstanak i sačuvali zdrav razum“" i krenuli u borbu „s demonima“. 50

Sasvim suprotno tome možemo pogledati šta se to „neguje“ u patokratiji, dakle: „U patokratiji svi vodeći položaji (od seoskog načelnika, preko upravnika zadruga, da ne pominjemo rukovodioce policijskih jedinica, snage specijalne policije i aktiviste patokratske partije) moraju biti popunjeni pojedincima s odgovarajućim psihološkim izopačenjima koja su obično nasleđena“. ${ }^{51}$ Negovanje ovakvih slojeva ili bolje rečeno aparatčika predstavlja „osnovu za kasniju tragediju“52 koja onda postaju neizbežne. Šta je sledeće? U ovakvoj društvenoj situaciji pravo i ostale oblasti života ne mogu da se razvijaju normalno jer „Patokratija progresivno parališe sve“. 53

Ono što vidimo uporedo sa paralizom onog normalnog u društvu je da se patokratija „progresivno nameće svuda i zaglupljuje sve”. ${ }^{44}$ Šta se onda dešava? Negde na marginama društva koje je od vlasti označeno kao adekvatno, prosperitetno, uvaženo, javlja se pored doživljaja straha, koji je kontinuiran, i doživljaj jasnog nezadovoljstva, te se samim tim i pojavljuje ,jaz između patokrata $i$ zajednice normalnih ljudi" ${ }^{55}$ To razdvajanje kod vlasti rađa ideju da sve što je suprotno njihovom načinu mišljenja njima preti i predstavlja za njih „duboko nemoralnu“ ${ }^{\text {"56 }}$ stvar. Tada su građani koji drugačije misle, čak i ako im se formalno u današnje vreme dopušta da drugačije misle, označeni kao protivnici zvanične ideologije što ih automatski kategoriše kao „ideološke neprijatelje“. ${ }^{57}$ Ovakvo podvajanje građana govori o vlasti koja je „zasnovana na fanatičnoj ideologijiifis i u stanju je da primeni „sve metode terora“. ${ }^{59}$ A šta je sa pravom takve države? Pored onog pisanog, pozitivnog prava postoji i ono

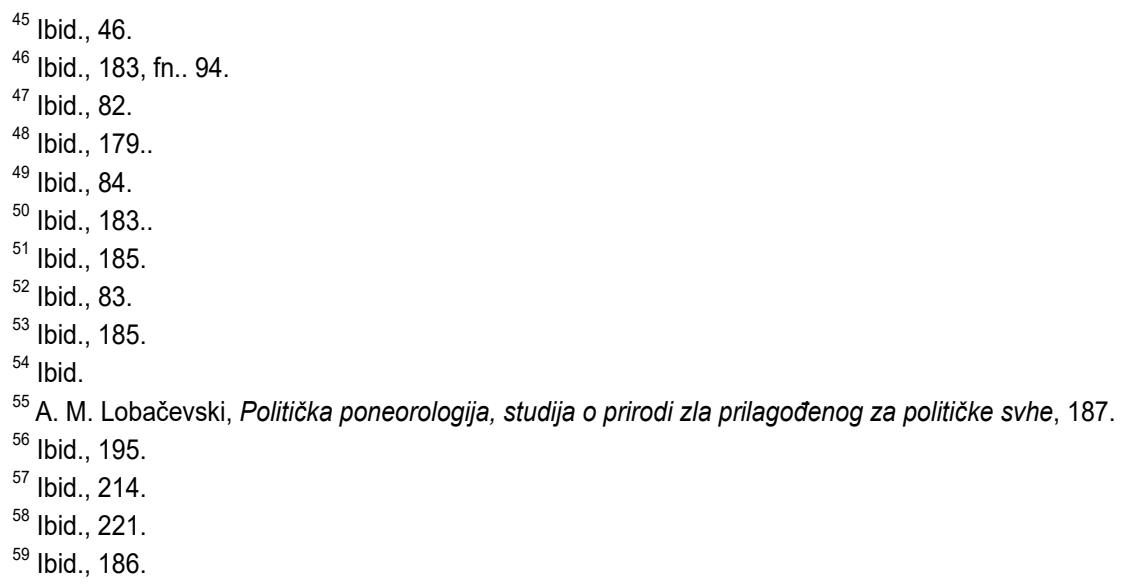


koje je u takvim državama ,jače“, to je „novi, nepisani zakon“ za koje građani saznaju putem veoma „bolnih iskustava“. ${ }^{60}$ Ovo se dešava u svakodnevnim stvarima na radnom mestu čoveka koji ne pripada ovoj „grupi“ te zbog toga: „Normalni ljudi moraju da razviju nivo strpljivosti izvan mogućnosti shvatanja bilo koga ko živi u društvu normalnog čoveka samo da bi objasnili nekom ograničenom mediokritetu koji pripada tim psihološkim izopačenicima šta i kako radi, a koji je postavljen da rukovodi nekim projektom koji niti može da razume, a još manje da njime upravlja“. ${ }^{61}$ A do ovoga dolazi ne samo zbog „nameštanja“ aparatčika na odgovorna mesta, već i zbog saznanja same vlasti da ipak "uposli“ i „obične" građane, jer takva vlast ipak shvata da: „Napokon, neko treba da obavlja posao za nas“. 62

Kada se pripadnici ovakve vlasti nađu u situaciji da mogu da vladaju oni imaju na umu sledeće: „To je mesto za nas, mi sada imamo domovinu u kojoj se naši snovi o vladanju tim 'drugim' mogu ostvariti. Najzad možemo živeti u sigurnosti i prosperitetu“."

Te se ovim potvrđuje stanovište da je danas vlast najvažniji element koji određuje državu, jer nije bitno nad čime vladaš, niti nad kime vladaš, bitno je samo da vladaš. Te tako ovakvi pripadnici vlasti koji nemaju nikakvu sposobnost preuzimaju vlast u „potpuno razorenom sastavu nacije“64 ali je sve ovo veoma kratko jer takav sistem ne može dugo da opstane. Ipak, ono što se nikada neće promeniti bez obzira na sve je konstatacija „mi i oni“" ${ }^{65}$ jer „patokrate nikada ne mogu da nauče da misle koristeći se normalnim ljudskim pojmovima“" 66 Jedna od najvećih zabluda građana koja je jedan od sigurnih razloga za nastanak ovakvih država je da postoji nešto što bi se moglo nazvati „prijateljska sila“. ${ }^{67}$ Takvo nešto nije nikada postojalo niti će postojati, jer vlast i moć nisu nešto što se može tim imenom nazvati.

Ciklično smenjivanje koliko toliko valjanih pravnih sistema i onih koji se karakterišu histeroidnim procesima i autokratskim tendencijama sigurno dovode do stvaranja potpuno iskrivljenih slika pravnih sistema. Ono što se danas pojavljuje kao ozbiljan problem u slici pravnog sistema je što se danas svaki pravni sistem, barem kada sam sebe predstavlja, naziva demokratskim, u kome je naravno na delu vladavina prava. Posebno je ovaj problem izražen u sistemima koji su nestabilni, ili su izašli iz kriza i ratova, te se kod njih pojavljuje još jedna veoma „interesantna“ činjenica, da se kod smene vlasti, što u ovim sistemima u kvalitetu ništa ne znači već samo znači da je druga "garnitura“ došla na vlast, da vlast sama sebe naziva demokratskom. U smislu formalne demokratije u pogledu izbora, ona, vlast, najčešće i jeste izabrana od strane naroda, dok je ostatak, odnosno oni koji su ostali izvan vlasti, a želeli su je, nazivaju nedemokratskom. Zato će se i pojaviti postavka da će konačna faza demokratskog konsolidovanja društva biti označena kao proces u kojem će demokratske institucije i demokratska praksa biti integrisane u političku kulturu, te će sve postati prirodni poredak stvari. ${ }^{68}$

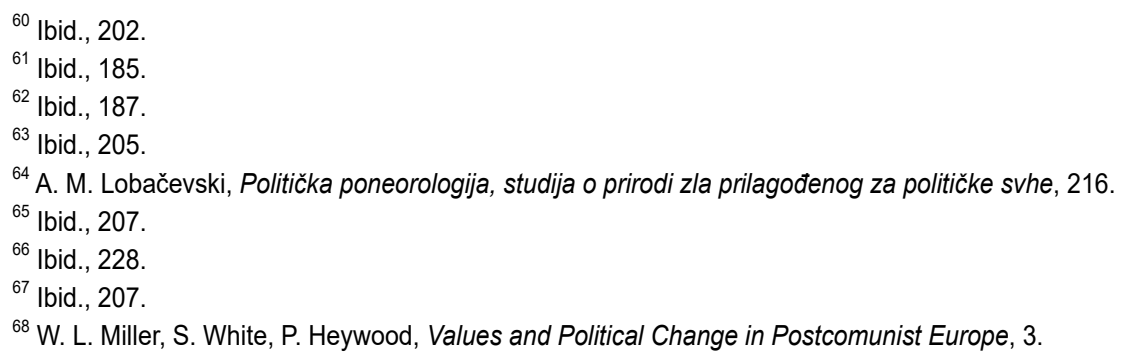


Ono što se neumitno ponavlja u ovim sistemima autoritarnog tipa je uloga partije koja je sveobuhvatna, od kontrole svih formi organizovanog života zajednice, preko izbora i administracije, pa do pisanja. Mehanizmi koji u ovom slučaju stoje na raspolaganju su partijsko kadroviranje ili potpuna kontrola nad svim postavljenjima na mesta od uticaja, potom tu je i kontrola protoka informacija do građana, koja je direktno vezana sa cenzurom. ${ }^{69}$ Uloga partije se najbolje oslikava otkrivajući onu realnu odliku partija a to je „Real sei nur das parteiinteresse, die Partiideologie ein bloß die, schöne Fassade dieses Interesses“. ${ }^{70}$

Izlazeći iz ere komunizma ovi sistemi su u pojedinim zemljama ponovili suštinske odlike totalitarnih sistema, koji su takvog karaktera da sloboda građana nije potpuno ostvarena, dok je uloga države rasprostranjena i to kroz delatnost političke partije i njene vlasti, koja usmerava svoju delatnost na sve sfere života, te su vrednosti bile od posebnog interesa za vladajuću partiju. ${ }^{71}$ Ovo je samo prirodni produžetak uređenja samih partija koje u takvim sistemima dolaze na vlast, jer je partija bila uređena na ideološkom i organizacionom jedinstvu, te se svaka manifestacija drugačijeg mišljenja shvatala kao neprihvatljiv vid frakcijskog delovanja, što je bilo nespojivo sa idejom članstva u partiji. ${ }^{72}$

Ni proces obrazovanja nije izuzet u ovim sistemima, jer partija ništa ne prepušta „slučaju" te tako i sam proces obrazovanja igra veoma važnu ulogu, stvarajući političku mladež sa kojom vlast komunicira preko istorije i drugih društvenih predmeta koji im se predaju u školama. ${ }^{73}$ Samim tim nema privatnog života izvan kruga porodice i prijatelja, mada je i taj život bio pod „budnim“ okom partije.

Mnogi od ovih režima bili su posvećeni izgradnji novih religija, iako to nisu tako zvali, ali se odanost komunističkoj partiji mogla izjednačiti sa religioznim zanosom. Ovo zato jer: „Auch eine solche Partei ware mit soziologischer Notwendigkeit gezwungen, sich eine ldeologie zu bilden, d. h. ihr Sonderinteresse als auch im Interesse der Allgemeinheit gelegen zum mindesten vorzugeben. Solche Parteiideologie wäre freiich zunächst nichts als das berückende Gewand, mit dem das Interesse seine Blöße deckt, aber mit soziologischer Zwangsläufigkeit wird sie bald mehr werden. Die Ideologie einer Partei wendet sich ja nicht hur kämpfend gegen den Garner, sondern auch werbend an neu zu gewinnende Anhanger. Um die Kerntruppe, die durch das Interesse an diese Partei gebunden ist, schart sich ein immer weiterer Kreis von Oarteimitgliedern, deren Parteizugehörigkeit nicht durch deshalb auf folgerichtige und restlose Durchführung der Idee auch auf Kosten des Interesses dringen und so die Partei an die Idee binden, die sie ihrerseits an die Partei gebunden hat". ${ }^{75}$ Ali, se taj zanos nikako nije mogao drugačije okarakterisati nego kao autoritarni put, protiv kojeg su se ipak borile mnoge snage u društu. Dakle, svi ovi režimi bili su posvećeni eliminaciji religije, gde će posebno veronauka postati nezakonita stvar ${ }^{76}$ a zapravo su stvarali novu religiju koju su samo drugačije nazivali, koju su brzo napuštali, jer je samo par

\footnotetext{
${ }^{69}$ W. L. Miller, S. White, P. Heywood, Values and Political Change in Postcomunist Europe, London, 1998, 34.

${ }^{70} \mathrm{G}$. Radbruch, Rechtsphilosophie, 58.

${ }^{71}$ W. L. Miller, S. White, P. Heywood, Values and Political Change in Postcomunist Europe, 35.

${ }^{72}$ lbid., 34.

${ }^{73}$ Ibid., 36.

${ }^{74}$ Ibid., 5.

${ }^{75} \mathrm{G}$. Radbruch, Rechtsphilosophie, 58.

${ }^{76}$ Ibid., 38.
} 
„trenutaka“ trebalo da se od smrti autoritarnog vođe napusti put veličanja i obožavanja njegovog lika i dela. Tako su se njegove slike istom brzinom stavljale i sklanjale sa zidova javnih institucija i škola, a istorija ponovo pisala, što je naravno po prirodi stvari dovodilo do „izgubljenih generacija“. ${ }^{77}$ Ali tu nije bio kraj jer su ostajali „stari aparatčiki bez komunističkih ideala“. ${ }^{78}$ Ono što im je ostalo kao konstanta i zalog prošlosti je koncept identifikacije sa partijom i njenom ideologijom. ${ }^{79}$ Taj koncept nisu napustili.

Dok danas pojedini narodi stoje „on the Ruins of Empire“"80 možemo postaviti i drugačije pitanje, šta je to sve tim sistemima bilo potrebno da ne bi postali iskrivljeni portret pravnog sistema?

Tako je najpre bilo potrebno da se uspostavi sistem u kome bi se valjalo zalagati sa jednak tretman i položaj svih građana i ograničenje vlasti. ${ }^{81}$ Ovo je prvi i osnovni uslov razvoja, svakog pravnog sistema u valjanom pravcu, istovremeno to je kamen spoticanja najvećeg broja pravnih sistema. Ovaj uslov predstavlja i konstantu koja predstavlja potrebu da se predupredi svaki arbitrerni postupak vlasti. ${ }^{2}$ Takođe ono što predstavlja nepoznanicu ovakvih pravnih sistema je činjenica da je neophodno prihvatiti da vlast mora da bude, jednako kao i građani, podređena zakonu. ${ }^{83}$

\section{Zaključak}

Valjanom pravnom sistemu ne treba ono o čemu svaki vođa „sanja“ a to je situacija u kojoj on, vođa nije ograničen zakonom. ${ }^{84}$ Društvu nisu potrebne poruke iz vrha političkih partija, nisu potrebni megalomanski zahtevi vlasti. Društvu je potrebna vlast koje je podređena zakonskim propisima, koja je iako je stvorila zakone njima podređena, u suprotnom mi se borimo protiv takvog pravnog sistema isto „tamquam e vinculis sermocinari“ ${ }^{185}$ (Bacon). I ono što je jedan od uslova da nikako ne dođe do krhotina prava je neophodnost obrazovanja, jer je teže manipulisati obrazovanom populacijom, no onom koja to nije. ${ }^{86}$

Sasvim suprotno od onoga što očekuje svaka vlast, koja sebe prikazuje kroz pravni sistem koji gradi, da ni građani ni pravnički stalež nikako ne označe i konstatuju da je pravni sistem jedne države izraz volje grupe na vlasti, mi konstatujemo kao Radbruh: „Ja, noch deine Gewalt selbst ist nicht als meine Furcht“" ${ }^{87}$ I odgovor na volju vlasti koja želi da nas zaplaši nalazimo u ideji „Qui potest mori, non potest cogi“ (Seneca). ${ }^{88} \mathrm{Na}$ na-

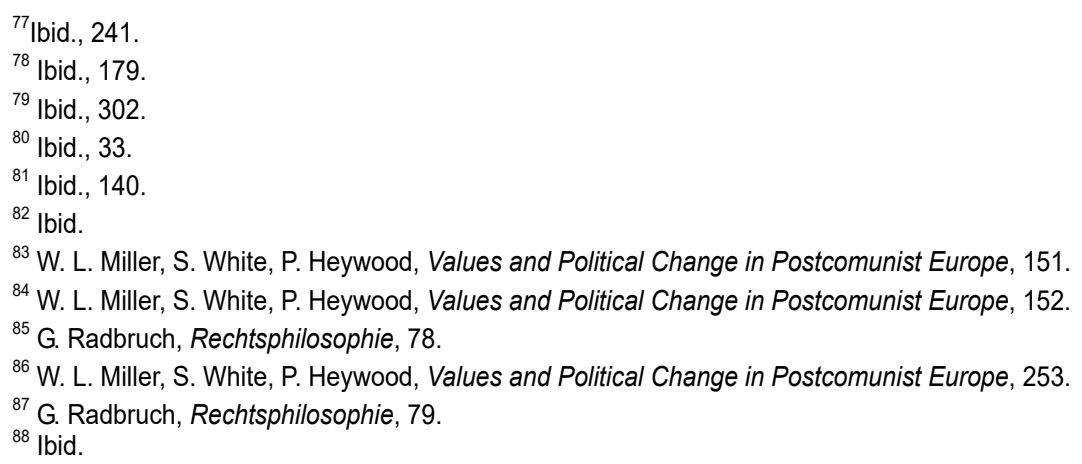


šu žalost, svaka sila se „seti“ svoje ograničenosti tek u trenutcima sopstvenih gubitaka te zato i stoji: „Wissen Sie, was micht auf deser Welt am meisten in Erstaunene setz? Es ist die Ohnmacht der materiellen Gewalt. Es gibt auf der Welt nur zwei Dinge, das Schwert und den Geist. Auf die dauer ist es immer der geist, der über das Schwert siegen wird“. ${ }^{89}$ Dakle, sledeći Radbruha nema „diese Blankohingabe der egenen Persönlichkeit an eine Rechtsordnung...". 90 Potvrdu za ovakvu misao nalazimo u stavu: „Ich habe geschworen, die Verfassung gewissenhaft zu beobachten: wie aber wenn mein Gewissen mir gebietet, sie nicht zu beobachten?"91

\section{Literatura}

[1] Lobačevski, A. M, Politička poneorologija, Naučna studija o prirodi zla prilagođenog za političke svrhe, Beograd, 2011.

[2] Marmor, A, Law in the Age of Pluralism, Oxfrod University Press, New York, 2007.

[3] Miller, W. L, White, S, Heywood, P, Values and Political Change in Postcomunist Europe, London, 1998.

[4] Radbruch, G, Rechtsphilosophie, Verlag Von Quelle \& Mezer in Leipzig, Leipzig 1932.

[5] Raz, J, Liberalism, Skepticism and Democracy, in Ethics in the Public Domain, Essays in the Morality of Law and Politics, Clarendon Press, Oxford, 1994.

[6] Raz, J, The Authority of Law, Oxford University Press, Oxford, 2009.

\footnotetext{
${ }^{89}$ lbid., 79, f. 4.

${ }^{90}$ lbid., 83.

${ }^{91}$ lbid., 84, fn. 1.
} 